\title{
KOMPARASI ANTARA TEMA EKOLOGI, EKONOMI, SOSIAL DAN BUDAYA DALAM FOTO LANSKAP BUDAYA SUBAK HASIL PHOTOVOICE MAHASISWA CALON GURU
}

\author{
Candra Manik Maheyeti, Sang Putu Kaler Surata, Dewa Ayu Puspawati \\ Program Studi Pendidikan Biologi, Fakultas Keguruan dan Ilmu Pendidikan, Universitas \\ Mahasaraswati Denpasar, Denpasar \\ E-mail: kertawira.lita@gmail.com
}

\begin{abstract}
ABSTRAK
Sistem subak terbentuk dari aspek ekonomi, ekologi, sosial dan budaya. Kemampuan untuk memahami keempat pilar tersebut sangat penting, terutama bagi pendidikan tinggi dalam menyiapkan mahasiswa calon guru sebagai fasilitator pendidikan. Tujuan dari penelitian ini adalah untuk membandingkan frekuensi tema foto tentang aspek ekologi, ekonomi, sosial dan budaya dari hasil photovoice mahasiswa calon guru. Penelitian berlangsung pada November 2018 sampai Januari 2019 di kampus UNMAS Soka dan subak di sekitar Kota Denpasar. Jenis penelitian ini merupakan penelitian campuran (mixed methods research) yakni penelitian dengan menggabungkan dua bentuk pendekatan: kualitatif dan kuantitatif dengan menggunakan design community-based participatory action research (CBPR). Sampel penelitian adalah 18 orang (4 laki-laki dan 14 perempuan) mahasiswa Program Studi Pendidikan Biologi Universitas Mahasaraswati, Tahun Akademik 2018/2019. Teknik analisis data yang digunakan adalah uji analisis varian (ANOVA). Hasil penelitian ini menunjukkan bahwa terdapat perbedaan nyata $(\mathrm{F}=6,973$ dan $\mathrm{P}=0,000)$ antara frekuensi tema ekologi, ekonomi, sosial dan budaya pada hasil photovoice mahasiswa calon guru, dengan nilai frekuensi ekologi 35, ekonomi 46, sosial 26, dan budaya 63.
\end{abstract}

Kata Kunci: Lanskap budaya subak, PuPB, photovoice, mahasiswa calon guru

\begin{abstract}
The subak system comprises four aspects, namely economic, ecological, social, and cultural aspects. It is important to have the abilities to understand these four pillars, especially for higher education in preparing students-teachers as educational facilitators. The aim of this study is to compare the frequency of photo themes in relation to ecological, economic, social, and cultural aspects yielded from photovoice results of student-teachers. This study was conducted from November 2018 to January 2019 at UNMAS Soka campus and several subak sites in Denpasar. This study was conducted in mixed methods where two approaches were utilised: qualitative and quantitative with community-based participatory action research (CBPR) as its design. There were 18 student-teachers (4 males and 14 females) of Biology Education Study Program, Universitas Mahasaraswati, Academic Year 2018/2019, participated in this study. The data analysis technique used was analysis of variance (ANOVA). The finding of this study showed that there was a significant difference $(F=6.973$ and $P=0.000)$ among the frequency of ecological, economic, social, and cultural themes of the student-teachers' photovoice results, with the frequency value of each theme in the following order: ecology $=35$, economy $=46$, social $=26$, and cultural $=63$.
\end{abstract}

Keywords: Subak cultural landscape, PuPB, photovoice, student-teachers. 


\section{PENDAHULUAN}

Lanskap budaya subak merupakan bentang yang dibentuk dari perpaduan antara berbagai faktor alam dan perilaku petani Bali dalam bercocok tanam padi di sawah selama lebih dari satu milenium (Surata, 2015). Kelestarian sistem subak terbentuk dari interaksi antara aspek ekonomi, ekologi, sosial dan budaya. Keempat aspek dari keberlanjutan dalam lanskap budaya subak (dan berbagai kearifan tradisional lain yang terdapat pada berbagai kawasan di dunia) oleh Badan Dunia untuk Pendidikan dan Kesehatan (UNESCO) telah dijadikan pilar utama dari pembangunan berkelanjutan (sustainable development) dan pendidikan untuk pembangunan berkelanjutan (education for sustainable development) (Surata, 2015).

Kemampuan untuk memahami empat pilar tersebut sangat penting, terutama bagi pendidikan tinggi yang diharapkan membantu menciptakan dunia yang lebih berkelanjutan (DuPuis, E. M., \& Ball, 2013). Terlebih-lebih bagi mahasiswa calon guru, yang di samping menjadi calon pemimpin di masa depan juga akan menjadi calon pendidik bagi calon peminpin pada masa depan. Karena itu, mereka terlebih dahulu perlu memahami empat pilar dalam konteks lingkungan lokal agar mampu menjadi fasilitator pendidikan untuk kehidupan berkelanjutan.

Sejauh ini, penelitian yang terkait dengan pilar pembangunan berkelanjutan dalam konteks lingkungan lokal masih belum banyak dilakukan. Padahal, publikasi hasil penelitian demikian dapat memperkaya referensi dan inspirasi bagi kajian dalam pendidikan berkelanjutan maupun menyiapkan mahasiswa calon guru sebagai fasilitator pendidikan berkelanjutan. Melalui penelitian ini juga secara tidak langsung turut mengasah kompetensi mahasiswa sebagai calon guru biologi yang berkompeten dalam pengembangan bahan ajar, perancangan dan pelaksanaan pembelajaran yang kreatif yang dapat mengasah pemahaman peserta didik serta pengembangan peserta didik untuk dapat mengaktualisasikan potensi yang dimilikinya melalui photovoice. Penelitian ini bermaksud mempelajari tema yang dihasilkan dari kegiatan photovoice mahasiswa calon guru untuk menemukan ada tidaknya perbedaan tema yang nyata antara foto tentang aspek ekologi, ekonomi, budaya dan sosial dari kegiatan photovoice.

\section{METODE PENELITIAN}

Jenis penelitian ini merupakan penelitian campuran (Mixed Methods research), penelitian dengan menggabungkan dua bentuk pendekatan, yaitu kualitatif dan kuantitatif (Creswell, $d k k 2007)$ (Sugiyono., 2018). Penelitian ini menggunakan rancangan communitybased participatory action research (kaji tindak partisipatif berbasis komunitas), tertutama dalam bentuk photovoice. Sampel penelitian adalah 18 orang mahasiswa Program Studi Pendidikan Biologi Universitas Mahasaraswati, yang menjadi peserta Mata Kuliah Ekopedadogi, pada Tahun Akademik 2018/2019. Mereka terdiri atas 4 laki-laki, dan 14 perempuan dengan usia rata-rata 21 tahun. Sebagian besar dari mereka (90\%) berasal dari Luar Propinsi Bali.Variabel terikat yang terdapat dalam penelitian ini adalah tema yang dikaji yaitu ekologi, ekonomi, sosail dan budaya sedangkan 
variable bebas adalah kegiatan photovoice. Proses pengumpulan data terintegrasi dengan pelaksanaan Kuliah Ekopedagogi dengan tahapan, 1) Diskusi Buku Lanskap Budaya Subak (Surata, 2013) dan Buku Ekopedagogi (Surata, 2015) dalam empat kali tatap muka (masing-masing 2x50 menit pembelajaran di dalam kelas) (Strand, K., Muralo, S., Cutforth, N., Stoecker, R., \& Donohoe, 2014).

Sebelum dilakukan penelitian terlebih dahulu melakukan validasi instrumen penelitian, validasi yang digunakan adalah validasi konstruk dengan dosen pembimbing dan menggunakan 2 macam reliabilitas: (1) inter - rater reliability, peneliti dan satu teman peneliti masing-masing melakukanan analisis foto kedalam tema tertentu, dan kemudian menghitung frekuensi tema untuk setiap foto dengan nilai korelasi yang diharapkan, (2) Uji intra-reliabilitas dilakukan oleh peneliti dengan menganalisis tema dalam judul foto sebanyak dua kali dalam kurun waktu tiga minggu dengan nilai korelasi yang diharapkan $r>0,06$. Teknik pengelolaan kelas menggunakan Jigsaw modifikasi. Mahasiswa terbagi menjadi empat kelompok asal, dan dalam setiap kelompok asal terdiri atas ahli bidang ekologi, ahli bidang sosial, ahli bidang ekonomi, dan ahli bidang budaya. Untuk memudahkan pengelolaan, digunakan kode abjad untuk kelompok asal, dan angka untuk kelompok ahli (Contoh A1 = berarti mahasiswa yang bersangkutan termasuk dalam kelompok asal A dan ahli1). 2) Mahasiswa melakukan perjalanan ke kawasan subak yang ada di sekitar Kota Denpasar. Setiap mahasiswa diminta melakukan wawancara dan mengambil foto langsung tentang berbagai aspek terkait dengan pendidikan keberlanjutan (5-10 foto untuk masingmasing aspek ekologi, ekonomi, sosial, budaya) dan memberi judul untuk masingmasing foto. 3) Foto yang telah terkumpul dari mahasiswa kemudian akan dipilih 5 foto dari peneliti secara acak berdasarkan kualiatas foto dan ketepatan judul.

\section{HASIL DAN PEMBAHASAN Hasil Penelitian}

Dalam tahap diskusi Buku Lanskap Budaya Subak (Surata, 2013) dan Buku Ekopedagogi (Surata, 2015) yang dilakukan oleh calon guru biologi dalam empat kali tatap muka dengan teknik pengelolaan kelas Jigsaw modifikasi dan menggunakan kode abjad untuk kelompok asal, dan angka untuk kelompok ahli guna mempermudah pengelolaan memperoleh hasil, para mahasiswa calon guru biologi sudah mampu mengidentifikasi serta menggolongkan tema atau aspek ekologi, ekonomi, sosial dan budaya.

Dalam perjalan ke Kawasan subak diperoleh hasil wawancara bersama pekaseh dan warga sekitar subak terkait tema ekologi, ekonomi, sosial dan budaya yang ada dalam Kawasan subak, serta masing-masing mahasiswa calon guru sudah mampu menuangkan keempat tema tersebut dalam sebuah hasil photovoice dan memberikan judul pada masingmasing foto yang diambil.

Dari hasil foto yang dikumpulkan dalam hasil photovoice berdasarkan kualitas dan ketepatan judul oleh mahasiswa calon guru diperoleh beberapa mahasiswa yang belum begitu paham akan tema dan pemberian judul yang tepat pada keempat aspek yang diamati serta pengambilan gambar yang kurang tepat dengan tema yang diamati. Data nilai 
frekuensi tema ekologi, ekonomi, sosial dan budaya disajikan pada Tabel 1

Tabel 1. Hasil Koding Permahasiswa Berdasarkan Tema Ekologi, Ekonomi, Sosial dan Budaya

\begin{tabular}{cccccc}
\hline No. Mahasiswa & Ekologi & Ekonomi & Sosial & Budaya & Jumlah \\
\hline 1 & 3 & 4 & 0 & 5 & 12 \\
2 & 1 & 4 & 2 & 5 & 12 \\
3 & 3 & 3 & 4 & 5 & 15 \\
4 & 2 & 3 & 1 & 5 & 11 \\
5 & 2 & 3 & 1 & 4 & 10 \\
6 & 2 & 2 & 0 & 4 & 8 \\
7 & 2 & 4 & 1 & 5 & 12 \\
8 & 1 & 1 & 1 & 5 & 8 \\
9 & 5 & 2 & 1 & 2 & 10 \\
10 & 1 & 1 & 0 & 0 & 2 \\
11 & 0 & 1 & 0 & 0 & 1 \\
12 & 1 & 2 & 2 & 5 & 10 \\
13 & 2 & 3 & 3 & 4 & 12 \\
14 & 3 & 2 & 4 & 5 & 14 \\
15 & 2 & 4 & 1 & 2 & 9 \\
16 & 5 & 4 & 4 & 5 & 18 \\
17 & 0 & 1 & 0 & 0 & 1 \\
18 & 0 & 2 & 1 & 2 & 5 \\
Jumlah & 35 & 46 & 26 & 63 & \\
\hline
\end{tabular}

Pada Tabel 1 terlihat bahwa nilai frekuensi paling rendah adalah pada tema sosial, hal ini disebabkan kurangnya pemahaman serta pemberian judul yang kurang tepat pada foto akan tema sosial yang ada pada area subak yang dikunjungi. Selain itu karena minimnya kegiatan sosial pada area subak yang dikunjungi sehingga sedikit sulit untuk menuangkannya dalam hasil photovoice.
Berdasarkan hasil uji statistik dengan bantuan program komputer, dengan uji Anova menunjukkan bahwa ke-empat tema (ekologi, ekonomi, sosial dan budaya) berbeda secara signifikan yang berarti Ha diterima, $\mathrm{H} 0$ ditolak. dengan taraf signifikansi sebesar $0,000>0,05$ dengan nilai $F$ sebesar 6.973. Untuk lebih jelas hasil analisis terdapat pada Tabel 2

Tabel 2. Hasil Uji Anova Hasil Photovoice

\begin{tabular}{lccccc}
\hline $\mathbf{N}=18$ & $\begin{array}{c}\text { Sum of } \\
\text { Squares }\end{array}$ & df & $\begin{array}{c}\text { Mean } \\
\text { Square }\end{array}$ & F & Sig. \\
\hline $\begin{array}{l}\text { Frekuensi antar } \\
\text { Kelompok }\end{array}$ & 45.375 & 3 & 15.125 & 6.973 & .000 \\
$\begin{array}{l}\text { Frekuensi dalam } \\
\begin{array}{l}\text { Kelompok } \\
\text { Total }\end{array}\end{array}$ & 147.500 & 68 & 2.169 & & \\
\hline
\end{tabular}




\section{PEMBAHASAN}

Berdasarkan analisis yang dilakukan, bahwa terdapat perbedaan frekuensi pada tema ekologi, ekonomi, sosial dan budaya pada hasil photovoice mahasiswa calon guru. Hal tersebut terlihat adanya perbedaan yang nyata antara tema ekologi, ekonomi, sosial dan budaya pada hasil photovoice mahasiswa calon guru dengan nilai $\mathrm{F}=6,973$ dan $\mathrm{P}=$ $0,000<0,05$.

Pada tema ekologi memperoleh nilai frekuensi 35 hal ini dikarenakan kurangnya pengetahuan mahasiswa calon guru dalam mengidentifikasi tema tersebut sehingga hasil photovoice kurang maksimal, masalah lainnya adalah terdapat pada area subak yang didatangi mahasiswa calon guru, kurangnya pengelolan dan pengetahuan tentang aspek ekologi mengakibatkan aspek ekologi tidak diperhitungkan dalam pengelolaan subak yang nantinya akan berimbas pada Pendidikan untuk pembangunan berkelanjutan hal ini juga disimpulkan dalam penelitian Surata (2013) yang mengatakan bahwa pemanfaatan subak menjadi model ekopedagogi yang didalamnya secara tidak langsung berhubungan dengan tingkat anorganisme serta berperan dalam pembelajaran lintas budaya yang berpotensi untuk mengatasi tantangan yang dihadapi dalam implementasi konsep Pendidikan untuk Pembangunan Berkelanjutan (PuPB).

Tema ekonomi dalam penelitian ini memperoleh nilai frekuensi hasil photovoice sebesar 46 dan merupakan aspek tertinggi kedua dalam empat aspek yang diamati. Hal tersebut dikarenakan pengelolaan ekonomi pada area subak yang cukup mendukung baik dari pengelolaan hasil panen, usaha kecil menengah pada area subak sampai dengan pemanfaatan limbah pertanian dan peternakan guna menekan pengeluaran dalam penggunaan bahan pendukung pertanian seperti pupuk yang nantinya secara tidak langsung akan berdampak pada meningkatnya aspek ekonomi. Penelitian ini turut mendukung penelitian dari (Yuwono, C.S.M. Felix, 2018) tentang sistem PertanianTerintegrasi (simantri) mengupayakan integrasi usaha budi daya tanaman dan ternak, dimana limbah tanaman diolah untuk pakan ternak dan cadangan pakan pada musim kemarau dan limbah ternak (faeces, urine) diolah menjadi biogas, biourine, pupuk organik dan biopestisida. Berbeda dengan penelitian penelitian (Windia, W., Ketut, S., \& Sumiyati, 2018) yang menyatakan subak sejatinya bukan lembaga ekonomi, tetapi lembaga sosio-kultural, subak disebutkan sebagai organisasi petani pengelola air irigasi yang bersifat sosio agraris religious. 
Tema sosial pada penelitian ini memperoleh nilai frekuensi paling rendah (26) jika dibadingkan dengan aspek lainnya, hal tersebut dikarenakan kurangnya kegiatan sosial pada setiap area subak yang dikunjungi seperti gotong royong yang saat ini sangat jarang ditemukan dalam area subak bahkan kehidupan sehari. Kegiatan sosial biasanya hanya akan berlangsung apabila ada perayaan hari besar dalam sistem pertanian contohnya dalam upacara pasca panen, padahal sejatinya subak merupakan komunitas sosial yang satu sama lainnya saling berhubungan sebagaimana yang tertuang dalam falsafah Tri Hita Karana (THK). Temuan ini didukung oleh penelitian dari (Tarigan, H., Arya, H.D., \& Kedi, 2012) yang mengatakan bahwa perubahan lingkungan pada daerah subak tidak bersifat netral, walaupun nilai produksi pangan dapat meningkatkan pertumbuhan ekonomi pada area subak namun hal tersebut dapat mereduksi faktor sosial kapital subak sehigga dapat menimbulkan disintegritas antar subak.

Tema budaya dalam frekuensi hasil photovoice mahasiswa calon guru memperoleh nilai frekuensi yang sangat tinggi yaitu sebesar 63. Hal ini tercermin dalam kehidupan masyarakat Bali yang sebagian besar masih memegang erat kebudayaannya dengan baik, sehingga tidak begitu sulit bagi mahasiswa calon guru untuk mengidentifikasi tema budaya yang ada pada sekitaran area subak. Hal tersebut bisa dijadikan sebagai acuan dalam mengembangkan pembelajaran kontektual berbasis budaya dalam mengembangkan Pendidikan yang mendukung pembangunan berkelanjutan. Penelitian ini didukung oleh penelitian (Setiawati, 2013) dalam penelitiannya menyatakan bahwa pembelajaran IPA dengan memanfaatkan subak merupakan wujud pembelajaran kontekstual yang menanamkan pendidikan karakter untuk menggerakkan peserta didik dan masyarakat berperan aktif dalam upaya pelestarian kebudayaan dan keselamatan lingkungan untuk generasi mendatang.

\section{PENUTUP}

\section{Simpulan}

Berdasarkan pemaparan hasil penelitian dan pembahasan, dapat disimpulkan bahwa terdapat perbedaan frekuensi antara aspek ekologi, ekonomi, budaya dan sosial dalam judul foto hasil photovoice mahasiswa calon guru dengan frekuensi tertinggi pada tema budaya (63) dan frekuensi terendah (26) pada tema sosial.

\section{Saran}

Berdasarkan hasil temuantemuan dalam penelitian, maka saran yang dapat disampaikan, sebagai berikut :

1. Bagi mahasiswa calon guru, perlu menerapkan pembelajaran dengan media photovoice untuk meningkatkan kreativitas dan berpikir kritis siswa.

2. Bagi peneliti lain, perlu lebih mendalami tentang empat tema PuPB untuk menghindari 
miskonsepsi sehingga hasil photovoice lebih tepat.

\section{DAFTAR PUSTAKA}

DuPuis, E. M., \& Ball, T. (2013). How not what: teaching sustainability as process. Sustainability: Science, Practice and Policy, http://www.tandfonline.com/doi/abs/ 10.1080/15487733.2013.11908108

Setiawati, G. A. . (2013). Pemanfaatan subak dalam pembelajaran ipa (upaya mewujudkan pembelajaran ipa yang mendukung implementasi kurikulum 2013.

Strand, K., Muralo, S., Cutforth, N., Stoecker, R., \& Donohoe, P. (2014). Community-based research and higereducatioan: principle and practices.

Sugiyono. (2018). Metode penelitian pendidikan (pendekatan kuantitatif, kualitatif, dan $R \& D)$. Alfabeta.

Surata, S. P. K. (2013). Pembelajaran lintas budaya: penggunaan subak sebagai model "Ecopedagogy". JURNAL KAJIAN BALI., 3(2).

Surata, S. P. K. (2015). Ekopedagogi. UNMAS PRESS Mahasaraswati Denpasar.

Tarigan, H., Arya, H.D., \& Kedi, S. (2012). Pertarungan akses sumber daya air keterancaman subak pada lahan persawahan di kabupaten tabanan, bali. Jurnal Analisis Kebijakan Pertanian, 5(2)., 126149.

Windia, W., Ketut, S., \& Sumiyati, W. T. (2018). Sistem subak untuk pengembangan lingkungan yang berlandaskan Tri Hita Karana. Journal on Socio-Economics of Agriculture and Agribusiness., 12 (1). 118-132. https://doi.org/10.24843/SOCA.2018 .v12.i01.p10

Yuwono, C.S.M. Felix, A. (2018). Outdoor learning dalam pembelajaran rekontekstualisasi prinsip 4f (food, feed, fuel, dan fertilizer) sistem pertanian terintegrasi (simantri). In Prosiding Seminar Nasional Pendidikan Biologi (p. ISBN: 978-602-61265-28),). 
